\title{
Genetic parameters of cheese yield and curd nutrient recovery or whey loss traits predicted using Fourier-transform infrared spectroscopy of samples collected during milk recording on Holstein, Brown Swiss, and Simmental dairy cows
}

\author{
A. Cecchinato, ${ }^{1}$ A. Albera, C. Cipolat-Gotet, A. Ferragina, and G. Bittante \\ Department of Agronomy, Food, Natural Resources, Animals and Environment (DAFNAE), University of Padova, Viale dell'Università 16, \\ 35020 Legnaro, Italy
}

\begin{abstract}
Cheese yield is the most important technological parameter in the dairy industry in many countries. The aim of this study was to infer (co)variance components for cheese yields (CY) and nutrient recoveries in curd (REC) predicted using Fourier-transform infrared (FTIR) spectroscopy of samples collected during milk recording on Holstein, Brown Swiss, and Simmental dairy cows. A total of 311,354 FTIR spectra representing the test-day records of 29,208 dairy cows (Holstein, Brown Swiss, and Simmental) from 654 herds, collected over a 3-yr period, were available for the study. The traits of interest for each cow consisted of 3 cheese yield traits (\%CY: fresh curd, curd total solids, and curd water as a percent of the weight of the processed milk), 4 curd nutrient recovery traits (REC: fat, protein, total solids, and the energy of the curd as a percent of the same nutrient in the processed milk), and 3 daily cheese production traits (daily fresh curd, total solids, and the water of the curd per cow). Calibration equations (freely available upon request to the corresponding author) were used to predict individual test-day observations for these traits. The (co)variance components were estimated for the CY, REC, milk production, and milk composition traits via a set of 4-trait analyses within each breed. All analyses were performed using REML and linear animal models. The heritabilities of the $\% \mathrm{CY}$ were always higher for Holstein and Brown Swiss cows (0.22 to 0.33) compared with Simmental cows (0.14 to 0.18$)$. In general, the fresh cheese yield $\left(\% \mathrm{CY}_{\mathrm{CURD}}\right)$ showed genetic variation and heritability estimates that were slightly higher than those of its components, $\% \mathrm{CY}_{\text {SOLIDS }}$ and $\% \mathrm{CY}_{\text {WATER }}$. The parameter $\mathrm{REC}_{\text {PROTEIN }}$ was the most heritable trait in all the 3 breeds, with
\end{abstract}

Received July 10, 2014.

Accepted March 27, 2015

${ }^{1}$ Corresponding author: alessio.cecchinato@unipd.it values ranging from 0.32 to 0.41 . Our estimation of the genetic relationships of the $\mathrm{CY}$ and REC with milk production and composition revealed that the current selection strategies used in dairy cattle are expected to exert only limited effects on the REC traits. Instead, breeders may be able to exploit genetic variations in the $\% \mathrm{CY}$, particularly $\mathrm{REC}_{\mathrm{FAT}}$ and $\mathrm{REC}_{\mathrm{PROTEIN}}$. This last component is not explained by the milk protein content, suggesting that its direct selection could be beneficial for cheese production aptitude. Collectively, our findings indicate that breeding strategies aimed at enhancing CY and REC could be easily and rapidly implemented for dairy cattle populations in which FTIR spectra are routinely acquired from individual milk samples.

Key words: genetic parameter, mid-infrared spectroscopy, cheese yield, whey loss, dairy breed

\section{INTRODUCTION}

The amount of milk used for cheese production is growing in many countries (International Dairy Federation, 2013), increasing the importance of the milk technological parameters that are related to dairy processing. Cheese yield (CY), which is the percentage ratio between the curd weight and the milk weight, is the most important parameter for the dairy industry and affects milk value (Emmons, 1993). Protein and fat, together with water, are the most important milk components retained in the curd, and CY is usually predicted from the milk protein and fat contents (Emmons et al., 1990; Verdier-Metz et al., 2001). This assumes that there is a linear relationship and constant recovery (REC) for milk nutrients in the curd (i.e., the percentage of a given milk nutrient that is retained in the curd).

In current dairy cattle breeding programs, the aptitude of milk for cheese production is improved via changes in milk composition, indirectly exploiting the 
favorable phenotypic relationships of the milk protein and fat contents with CY. Individual variations in the recoveries of protein $\left(\mathbf{R E C} \mathbf{C}_{\text {PROTEIN }}\right)$ and fat $\left(\mathbf{R E C}_{\mathbf{F A T}}\right)$ are not considered. In a study on individual model cheeses fabricated from the milk of individual Brown Swiss cows, however, Bittante et al. (2013) showed that CY has genetic variability and a moderate heritability. Those authors also found that, although the genetic correlations of the milk fat and protein contents with CY were positive and high, the milk composition did not explain all of the genetic variation observed in CY. Othmane et al., (2002a) used a very simplified procedure in which $10 \mathrm{~mL}$ of milk was heated, rennet was added, milk was centrifuged after $1 \mathrm{hr}$, then drained and weighed (Othmane et al., 2002b); they estimated that CY of ovine milk is characterized by a rather low heritability (about one-half that of milk yield and onethird that of protein content).

The recoveries of protein and fat in the curd are genetically controlled traits, with high and moderate heritability values, respectively (Bittante et al., 2013). Their genetic relationships with the corresponding nutrient contents in the milk are low, whereas they show positive and consistent genetic correlations with $\mathrm{CY}$ (Bittante et al., 2013). Hence, breeders could perhaps more effectively improve the aptitude of milk for cheese production if they selected directly for technological parameters rather than for milk composition. However, such selection has been limited by the relative lack of phenotypic data; a routine genetic evaluation would require population-level data for individual $\mathrm{CY}$ or $\mathrm{REC}$ traits, but such work is clearly infeasible for both operative and economic reasons.

Infrared optical technologies, such as Fourier-transform infrared (FTIR) spectroscopy, have proven to be efficient in predicting a variety of chemical bonds (Brandt et al., 2010; Karoui et al., 2010) and can be used to predict milk characteristics (Rutten et al., 2009; Karoui et al., 2011; Rutten et al., 2011). Indeed, within current milk-recording schemes, milk samples are routinely analyzed for their protein and fat contents using FTIR (ICAR, 2012). As FTIR spectra are now obtained for every milk sample collected during milk recording activities, we speculated that the use of appropriate calibration equations could enable the inexpensive large-scale analysis of multiple new phenotypes that might be incorporated into the current breeding programs.

In the FTIR spectra of milk, the transmittance of many individual waves in the range from wavenumber $5.000 \times \mathrm{cm}^{-1}$ (in the near-infrared interval) to $930 \times$ $\mathrm{cm}^{-1}$ (in the mid-infrared interval) was found to be heritable (Bittante and Cecchinato, 2013), as were the principal components obtained from the milk spectra (Soyeurt et al., 2010; Dagnachew et al., 2013). Bittante and Cecchinato (2013) also showed that the many heritable individual waves of the milk spectra included some whose transmittances are typically linked to the chemical bonds that characterize important components of milk. These findings provided the biological basis for using FTIR-based predictions for the selection of dairy species. Recent studies have examined the possible use of population-level FTIR predictions for the genetic improvement of milk characteristics, including the milk FA profile (Soyeurt et al., 2007b; Arnould et al., 2010; Bastin et al., 2011) and protein content (Soyeurt et al., 2007a; Arnould et al., 2009).

Cecchinato et al. (2009) showed that mid-infraredbased predictions of milk coagulation properties could be used for genetic improvement even when the predictive values of the calibration equations were moderate, as these traits were heritable and displayed genetic correlations that were much higher than the phenotypic correlations with the corresponding measured traits. Similar results were found by Rutten et al. (2010) for the milk FA profile and by Cecchinato et al. (2011a) for beef quality traits.

Ferragina et al. (2013) used FTIR spectroscopy to predict different measures of the $\mathrm{CY}$ and REC traits in Brown Swiss cows and obtained moderate to highly accurate predictions for most of them, except for RECFAT, for which the coefficient of determination between the predicted and measured values in cross-validation was equal to 0.41. In an external validation study, Bittante et al. (2014) compared the genetic parameters of FTIR predictions with those of the observed measures for CY and REC traits in Brown Swiss cows. For all of the considered traits, the heritabilities of the FTIR predictions were similar to or higher than those of the measured traits; furthermore, the genetic correlations between the predicted and observed measures were very high for all the traits. These results suggest that it may be possible to consider the FTIR predictions as potentials indicators traits for enhancing $\mathrm{CY}$ and REC traits at genetic level and, as a consequence, to apply a population-level selection scheme aimed at improving the CY-related traits in dairy cattle. However, this would require specific knowledge of the (co)variance components and heritabilities of the predicted traits in different dairy breeds. Therefore, the objective of our study was to estimate the genetic parameters for the FTIR predictions of various CY and REC traits at the population level (as obtained during routine milk recording data collection) and examine their genetic relationships with milk production and composition traits in Holstein, Brown Swiss, and Simmental cows. 


\section{MATERIALS AND METHODS}

\section{Data and Records}

The data for our study were provided by the Breeders Federation of Trento Province (in the northeast Italian Alps) as a part of the Cowplus Project. In Italy, individual samples are collected during routine milk recording and the milk composition of each sample is predicted by FTIR spectroscopy (ICAR, 2012). Since 2010, the FTIR spectra of all such milk samples obtained from the dairy herds of Trento province have been stored by the local Breeders Federation (FPA, Trento, Italy). A total of 311,354 FTIR spectra from the test-day records of 29,208 Brown Swiss, Holstein, and Simmental cows from 654 herds, obtained over $3 \mathrm{yr}$, were available for the current study. The herds were located in a mountainous area and were managed within the production systems described in Sturaro et al. (2013).

Only records from cows with known parents, at least 2 test-day records within lactation, and between 5 and 380 DIM have been included. The minimum size of contemporary groups, formed by cows of the same breed controlled in the same herd and in the same day, was set to 8 for Holstein and Brown Swiss and to 5 for Simmental due to the smaller average herd size for this breed. Records with response variables outside the range of mean \pm 3 standard deviation units were discarded. After editing procedures, the number of records available for statistical analyses in each breed was 84,732 for Holstein, 70,321 for Brown Swiss, and 19,333 for Simmental; the corresponding numbers of included cows were $8,786,7,342$, and 2,037 (Table 1).

\section{Genetic Background of Breeds}

The populations of the 3 breeds considered in our study show a genetic background directly related to best international selection. In fact, even if the majority of used AI bulls are of Italian origin (Table 2), the large majority of the sires of the AI bulls of all breeds belong to the most important populations internationally available. Sires of the bulls whose semen was used on the Holstein cows were mainly of North American and, to a lesser extent, European origin; in Brown Swiss, the sires of AI bulls were mainly of Italian, US, and German origin; in Simmental, dual-purpose cows were from German-Austrian (Fleckvieh) and French (Montbeliarde) origin (Table 2). The Italian selection indices used for the 3 investigated breeds included milk yield, milk quality, type traits (especially udder traits), and functional traits, as used in many other countries. For Brown Swiss, some emphasis is also given to technological properties of milk (including in the selection index also the $\kappa$-CN genotype), whereas in Simmental meat production also plays an important role.

\section{Calibration Equations and Traits Definitions}

The calibration equations developed by Ferragina et al. (2013; freely available by requesting them from the first author of the current paper) were used to predict the individual test day observations for traits related to CY. The data used for the calibrations were obtained from individual model cheese manufacturing from 1,264 Brown Swiss cows reared in 85 herds representing the different areas and dairy systems of the Trento province and sampled in different seasons of the year (Ferragina et al., 2013).

A preliminary analysis was carried out to identify the outlier spectra calculating the Mahalanobis distance. Spectra outside the range of mean \pm 3 standard deviation units were discarded $(0.3,0.2$, and $0.3 \%$ for Holstein, Brown Swiss, and Simmental cows, respectively). The Mahalanobis distance of the FTIR spectra were very similar in the 3 breeds (mean \pm SD: $387 \pm$ 152, $393 \pm 153$, and $392 \pm 154$ for Holstein, Brown Swiss, and Simmental cows, respectively). Moreover, as reported in Figure 1, the almost complete overlap between FTIR spectra of a different data set over the entire wavenumber range supports the application of such calibration equations at the population level of the 3 breeds.

Table 1. Summary of data available after editing

\begin{tabular}{lccc}
\hline Item (no.) & Holstein & Brown Swiss & Simmental \\
\hline Records $^{1}$ & $81,847-84,732$ & $68,456-70,321$ & $18,634-19,333$ \\
Herds & 170 & 259 & 121 \\
Herd by test date & 3,040 & 4,020 & 1,671 \\
Lactations with FTIR $^{2}$ recorded & 14,466 & 12,585 & 3,873 \\
Cows with FTIR and milk yield & 8,786 & 7,342 & 2,037 \\
Average records per cow & 9.6 & 9.6 & 9.5 \\
Animals with pedigree & 28,783 & 29,262 & 6,885 \\
\hline
\end{tabular}

${ }^{1}$ Number of records varies according to traits.

${ }^{2} \mathrm{FTIR}=$ Fourier-transform infrared spectroscopy. 
Table 2. Summary of pedigree information

\begin{tabular}{|c|c|c|c|c|c|c|}
\hline Item & \multicolumn{2}{|c|}{ Holstein } & \multicolumn{2}{|c|}{ Brown Swiss } & \multicolumn{2}{|c|}{ Simmental } \\
\hline Bulls (no.) & 1,908 & 355 & 986 & 165 & 681 & 153 \\
\hline Daughters of bulls $\geq 5$ daughters (\%) & 69 & - & 85 & - & 58 & - \\
\hline \multicolumn{7}{|l|}{ Country of origin of bulls (\%) } \\
\hline Italy & 61 & 13 & 57 & 38 & 40 & 14 \\
\hline France & 3 & 4 & 0.5 & - & 5 & 25 \\
\hline Germany & 13 & 11 & 14 & 18 & 30 & 49 \\
\hline the Netherlands & 8 & 10 & - & - & - & - \\
\hline Switzerland & 1 & - & 6 & 6 & - & - \\
\hline United States & 9 & 50 & 7 & 36 & - & - \\
\hline Other countries & 2 & 1 & 0.5 & 2 & - & - \\
\hline
\end{tabular}

The predicted traits included the fresh cheese yield $\left(\mathbf{\%}_{\mathbf{C Y}} \mathbf{C U R D}\right)$, the total solid cheese yield $(\mathbf{\%} \mathbf{C Y}$ SOLIDS $)$, and the water retained in curd (\% $\mathbf{C Y}$ WATER), all expressed as a percentage of the processed milk, and the nutrient recoveries of fat $\left(\mathbf{R E C} \mathbf{C A T}_{\mathrm{FAT}}\right)$, protein $\left(\mathbf{R E C}_{\text {PROTEIN }}\right)$, total solids $\left(\mathbf{R E C}_{\text {SOLIDS }}\right)$, and energy ( REC $_{\text {ENERGY }}$ ) in the curd as a percentage of the same nutrient contained in the milk (the difference between each REC and $100 \%$ was taken as the nutrient loss in the whey). Also, traits displaying calibration equations of low to moderate accuracy, such as $\mathrm{REC}_{\mathrm{FAT}}$ and $\% \mathrm{CY}_{\text {WATER }}$, were considered in the study because it

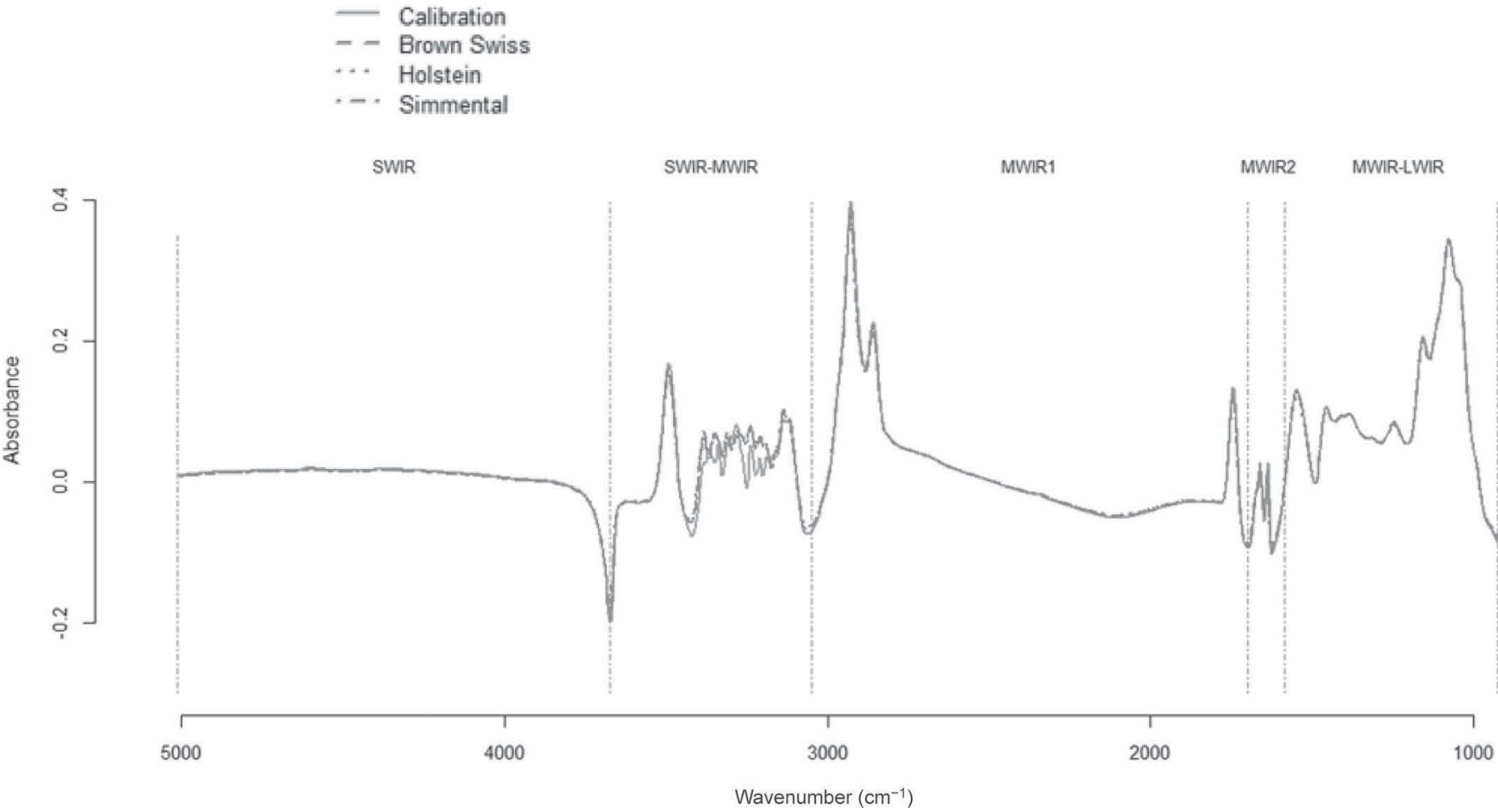

Figure 1. Plot of the average Fourier-transform infrared spectra absorbance of milk samples for the calibration set and for samples collected during milk recording on Holstein, Brown Swiss, and Simmental dairy cows. The spectrum is divided in different regions according to Bittante and Cecchinato (2013): 2 regions, one in the transition area between the short-wavelength infrared (SWIR) and mid-wavelength infrared (MWIR) divisions of the electromagnetic spectrum (SWIR-MWIR region) and another very short region in the MWIR division (MWIR2 region). Some discrepancies are visible only in the regions of the spectra affected by water (SWIR-MWIR and MWIR2). 
was previously demonstrated that additive genetic correlations between measures and predictions were much higher than the phenotypic ones (Bittante et al., 2014).

In addition to the \% $\mathrm{CY}$ and $\mathrm{REC}$ traits, the daily milk yield (dMY), fat, protein, and lactose percentages, and the SCS of each individual test day were available. The daily fresh cheese yield $\left(\mathbf{d C Y}_{\mathbf{C U R D}}\right)$, solid cheese yield ( $\left.\mathbf{d} \mathbf{C} \mathbf{Y}_{\text {Solids }}\right)$, and water cheese yield (dCY $\left.\mathbf{d C A T E R}_{\text {WA }}\right)$ were obtained as dMY times the corresponding predicted \%CY. Details on the definitions and calculations of the predicted traits can be found in Cipolat-Gotet et al. (2013).

\section{Statistical Analysis}

Nongenetic Effects. To begin, the GLM procedure (SAS Institute Inc., Cary, NC) was used to identify the nongenetic effects that should be included in our model for estimating the (co)variance components. For each trait and breed, the final model included the fixed effects of the herd by test date (4,020, 3,040, and 1,671 levels in Brown Swiss, Holstein, and Simmental cows, respectively), the DIM of each cow within parity (108 levels), and the year by season of calving (8 levels). Days in milk was treated as a classification variable; it had 11 monthly classes ranging from $<30$ to $330 \mathrm{~d}$, and 1 additional class for observations over $330 \mathrm{~d}$. The parity effect was modeled in 9 classes: parities of $>4,4$, and 3 were modeled as such; in parities 1 and 2 we also considered the effect of age at calving ( 3 classes within each parity) to account for different degrees of maturity at the beginning of lactation. Two seasons of calving were considered: April to September and October to March.

Genetic Analysis. The (co)variance components were estimated by the REML algorithm using the VCE software, v.6 (Neumaier and Groeneveld, 1998; Groeneveld et al., 2010). As computational limitations made it infeasible to perform a multivariate analysis that simultaneously included all of the available traits, the genetic parameters were estimated by fitting several 4-trait analyses within each breed. The multivariate mixed model was

$$
\mathbf{y}=\mathbf{X b}+\mathbf{Z}_{\mathrm{a}} \mathbf{a}+\mathbf{Z}_{\mathrm{pe}} \mathbf{p e}+\mathbf{e},
$$

where $\mathbf{y}$ is the vector of observations for 4 traits (i.e., the CY, REC, or milk composition traits and the single test-day milk yield); $\mathbf{b}, \mathbf{a}$, pe, and $\mathbf{e}$, are vectors representing unknown fixed nongenetic effects, random animal additive genetic effects, random permanent environmental effects, and random residuals effects, respectively; and $\mathbf{X}, \mathbf{Z}_{\mathrm{a}}$, and $\mathbf{Z}_{\mathrm{pe}}$ are incidence matrices (of appropriate order) relating observations in $\mathbf{y}$ to $\mathbf{b}$, a, and pe, respectively.

Conditional on the unknown parameters of the model, the data were assumed to be generated from the multivariate normal (MVN) distribution

$$
\mathbf{y} \mid \mathbf{b}, \mathbf{a}, \mathbf{E} \sim \operatorname{MVN}\left(\mathrm{Xb}+\mathrm{Z}_{\mathrm{a}} \mathbf{a}+\mathrm{Z}_{\mathrm{pe}} \mathbf{p e}, \mathbf{E}\right) .
$$

Random effects were assumed to be normally distributed with null mean and variances equal to

$$
\operatorname{Var}\left|\begin{array}{c}
\mathbf{a} \\
\mathbf{p e} \\
\mathbf{e}
\end{array}\right|=\left|\begin{array}{ccc}
\mathbf{G} \otimes \mathbf{A} & \mathbf{0} & \mathbf{0} \\
\mathbf{0} & \mathbf{P} \otimes \mathbf{I}_{\mathbf{c}} & \mathbf{0} \\
\mathbf{0} & \mathbf{0} & \mathbf{E} \otimes \mathbf{I}_{\mathbf{o}}
\end{array}\right|,
$$

where $\mathbf{G}, \mathbf{P}$, and $\mathbf{E}$ are the (co)variance matrices among the 4 traits for the animal, the permanent environmental effects, and the residual effects, respectively; $\mathbf{A}$ is the numerator of Wright's relationship matrix; $\mathbf{I}_{\mathbf{c}}$ and $\mathbf{I}_{\mathbf{o}}$ are identity matrices of size $\mathbf{c}$ and $\mathbf{o}$, respectively; $\mathbf{c}$ and $\mathbf{o}$ denote the number of cows and observations, respectively; and $\otimes$ is the Kronecker product operator. Additive relationships in $\mathbf{A}$ were computed using a pedigree file that included all phenotyped animals and their ancestors $(28,783,29,262$, and 6,885 animals in Holstein, Brown Swiss, and Simmental breeds with several average equivalent complete generations of 3.5 , 3.7 , and 2.4, respectively; Table 1 ).

\section{RESULTS}

\section{Descriptive Statistics}

Table 3 presents descriptive statistics for the investigated traits. All of the \%CY were higher in Brown Swiss cows followed by Simmental cows, whereas Holstein cows always showed lower values. The CY also displayed very high variabilities $(\mathrm{CV}=12-16 \%)$. In each breed, the contribution of water $\left(\% \mathrm{CY}_{\text {WATER }}\right)$ to the total fresh cheese yield ( $\left.\% \mathrm{CY}_{\mathrm{CURD}}\right)$ was around $55 \%$, and was thus higher than that of $\% \mathrm{CY}_{\text {SOLIDS }}(45 \%)$.

Compared with the CY, the REC showed much lower variabilities ( $\mathrm{CV}$ ranged from $3 \%$ for $\mathrm{REC}_{\text {PRoteIN }}$ to $7 \%$ for $\left.\mathrm{REC}_{\text {SOLIDS }}\right)$, but the breeds ranked in the same order. Around $50 \%$ of the milk TS were retained in the curd, mainly resulting from large proportions of fat (over $85 \%$ ) and protein (over $76 \%$ ) being recovered in the fresh cheese.

Compared with Holstein cows, the daily milk productions of Brown Swiss and Simmental cows were 15 and $23 \%$ lower, respectively; this affected the breed order for all of the daily cheese yields. The milk composition 
Table 3. Descriptive statistics of cheese yields (\%CY; weight of fresh curd, curd solids, and curd water as percentage of weight of milk processed), milk nutrient recovery (REC; protein, fat, solids, and energy of the curd as percentage of the protein, fat, solids, and energy of the milk processed), and daily production (dCY; curd, curd solids, and curd water produced daily per cow) for Holstein, Brown Swiss, and Simmental cows ${ }^{1}$

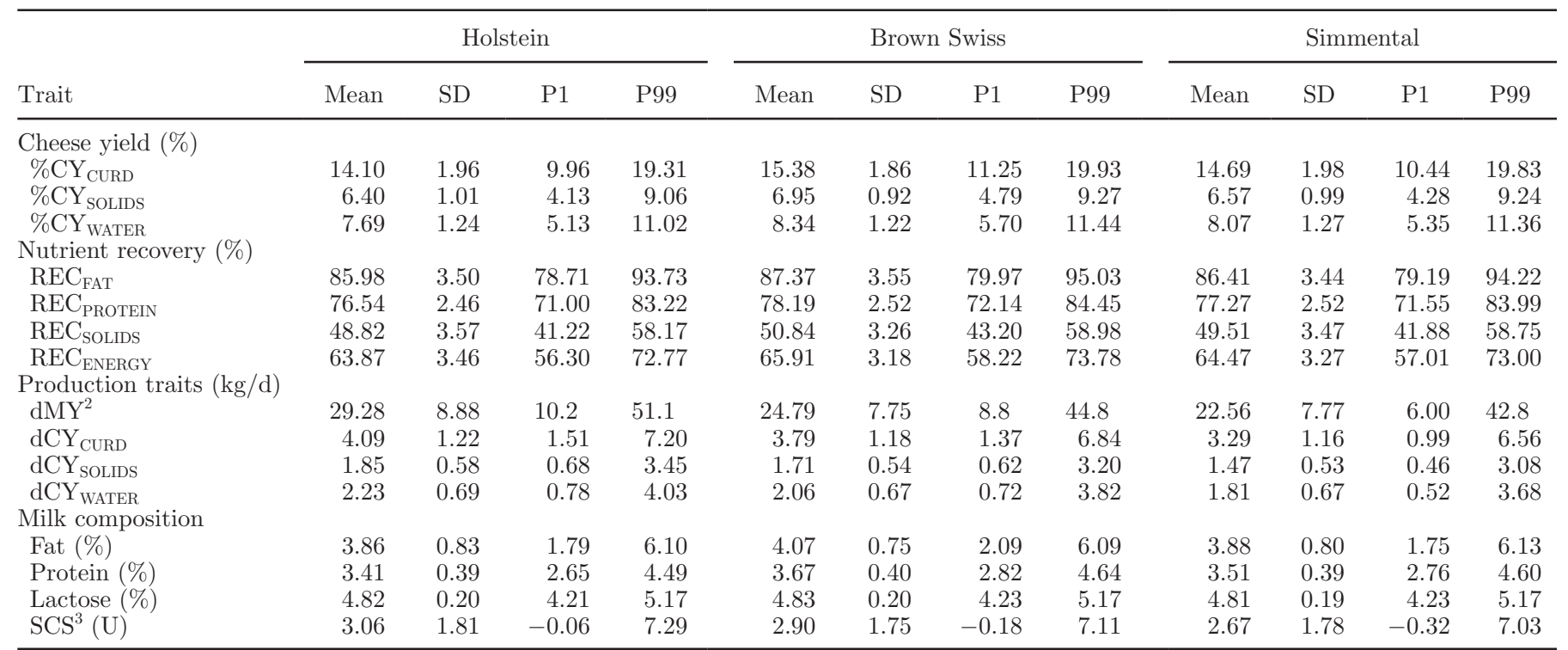

${ }^{1} \mathrm{P} 1=1$ st percentile; $\mathrm{P} 99=99$ th percentile.

${ }^{2} \mathrm{dMY}=$ daily milk yield

${ }^{3} \mathrm{SCS}=\log _{2}\left(\mathrm{SCC} \times 100,000^{-1}\right)+3$.

(in terms of the fat and protein percentages) was more favorable in Brown Swiss cows, whereas the lactose content showed limited variations across and within the tested breeds. The values of SCS followed the same breed order seen for milk production.

\section{Heritability and Repeatability}

Estimates of additive genetic variances, heritabilities, and repeatabilities are presented in Table 4. For all traits, our inferences of additive genetic variation, heritability, and repeatability were based on pooled estimates obtained in multivariate analyses. The heritabilities of the CY traits were always larger for Holstein and Brown Swiss cows (0.22 to 0.33) compared with Simmental cows $(0.14$ to 0.18$)$. In general, the total fresh cheese yield $\left(\% \mathrm{CY}_{\mathrm{CURD}}\right)$ displayed slightly higher genetic variabilities and heritabilities than those of its components, $\% \mathrm{CY}_{\text {SOLIDS }}$ and $\% \mathrm{CY}_{\text {WATER }}$. Permanent environmental effects were found to affect all of the CY parameters, yielding repeatability values between 0.32 and 0.47 , depending on the breed.

The heritability estimates for the milk production and $\mathrm{dCY}$ traits were consistent across the breeds and were much lower than those of the $\% \mathrm{CY}$, at 0.06 to 0.11. As expected, the permanent environmental variances were large for all of the production traits; hence, the repeatabilities were about 4 times higher than the heritabilities.

The $\mathrm{REC}_{\text {SOLIDS }}$ and $\mathrm{REC}_{\text {ENERGY }}$ had higher additive genetic variances and higher residual variances compared with $\mathrm{REC}_{\text {PROTEIN }}$ and $\mathrm{REC}_{\mathrm{FAT}}$. The $\mathrm{REC}_{\text {PROTEIN }}$ was the most heritable trait in all 3 breeds ( 0.32 to 0.41 ) and also had a high repeatability (0.45 to 0.53 ). Interestingly, this was the only trait among the \%CY and REC for which the heritability value in Simmental cows (0.35) was comparable to those of the other breeds. Similar heritabilities and repeatabilities were found for $\mathrm{REC}_{\text {SOLIDS }}, \mathrm{REC}_{\text {ENERGY }}$, and $\mathrm{REC}_{\mathrm{FAT}}$ within each breed. However, $\mathrm{REC}_{\mathrm{FAT}}$ was more (Holstein and Brown Swiss) or equally (Simmental) heritable compared with the milk fat content. The results for RECPROTEIN were similar to those of the protein percentage, displaying a heritability that was greater than that of the milk content in Brown Swiss and Simmental cows.

\section{Phenotypic and Genetic Correlations Between CY and REC}

All of the $\% \mathrm{CY}$ were heavily correlated with each other from the genetic point of view, with values ranging from 0.92 to 0.99 (Table 5). The corresponding phenotypic correlations were slightly lower (as in the case of $\% \mathrm{CY}_{\text {CURD }}$ with its components, $\% \mathrm{CY}_{\text {SOLIDS }}$ and 
Table 4. Pooled estimates of additive genetic variance $\left(\sigma_{a}^{2}\right)$, heritability $\left(\mathrm{h}^{2}\right)$, and repeatability $(\mathrm{RPT})$ for cheese yields $(\% \mathrm{CY}$; weight of fresh curd, curd solids, and curd water as percentage of weight of milk processed), milk nutrient recovery (REC; protein, fat, solids, and energy of the curd as percentage of the protein, fat, solids, and energy of the milk processed), daily production (dCY; curd, curd solids, and curd water produced daily per cow), and milk composition in Holstein, Brown Swiss, and Simmental cows ${ }^{1}$

\begin{tabular}{|c|c|c|c|c|c|c|c|c|c|}
\hline \multirow[b]{2}{*}{ Trait } & \multicolumn{3}{|c|}{$\sigma_{a}^{2}$} & \multicolumn{3}{|c|}{$\mathrm{h}^{2}$} & \multicolumn{3}{|c|}{$\mathrm{RPT}$} \\
\hline & Holstein & $\begin{array}{c}\text { Brown } \\
\text { Swiss }\end{array}$ & Simmental & Holstein & $\begin{array}{l}\text { Brown } \\
\text { Swiss }\end{array}$ & Simmental & Holstein & $\begin{array}{l}\text { Brown } \\
\text { Swiss }\end{array}$ & Simmental \\
\hline \multicolumn{10}{|c|}{ Cheese yield (\%) } \\
\hline$\% \mathrm{CY}_{\mathrm{CURD}}$ & 0.803 & 0.570 & 0.381 & 0.327 & 0.280 & 0.181 & 0.468 & 0.423 & 0.378 \\
\hline$\% \mathrm{CY}_{\text {SOLDS }}$ & 0.201 & 0.123 & 0.109 & 0.276 & 0.215 & 0.182 & 0.400 & 0.331 & 0.319 \\
\hline$\% \mathrm{CY}_{\text {WATER }}$ & 0.193 & 0.150 & 0.081 & 0.293 & 0.262 & 0.137 & 0.421 & 0.395 & 0.332 \\
\hline \multicolumn{10}{|c|}{ Nutrient recovery (\%) } \\
\hline REC $_{\text {PROTEIN }}$ & 1.120 & 1.605 & 1.237 & 0.316 & 0.412 & 0.354 & 0.454 & 0.528 & 0.447 \\
\hline $\mathrm{REC}_{\text {SOLIDS }}$ & 2.525 & 1.612 & 1.158 & 0.292 & 0.249 & 0.168 & 0.412 & 0.346 & 0.320 \\
\hline $\mathrm{REC}_{\text {ENERGY }}$ & 2.518 & 1.813 & 1.265 & 0.296 & 0.267 & 0.185 & 0.406 & 0.348 & 0.315 \\
\hline \multicolumn{10}{|c|}{ Production traits $(\mathrm{kg} / \mathrm{d})$} \\
\hline dMilk yield & 3.468 & 2.470 & 2.246 & 0.094 & 0.102 & 0.105 & 0.427 & 0.461 & 0.425 \\
\hline $\mathrm{dCY}_{\mathrm{CURD}}$ & 0.061 & 0.046 & 0.042 & 0.082 & 0.078 & 0.087 & 0.378 & 0.406 & 0.362 \\
\hline $\mathrm{dCY}_{\text {SOLIDS }}$ & 0.013 & 0.008 & 0.010 & 0.077 & 0.062 & 0.090 & 0.352 & 0.377 & 0.346 \\
\hline Lactose $(\%)$ & 0.009 & 0.008 & 0.007 & 0.283 & 0.260 & 0.258 & 0.477 & 0.449 & 0.439 \\
\hline $\operatorname{SCS}^{2}(\mathrm{U})$ & 0.232 & 0.205 & 0.268 & 0.082 & 0.081 & 0.102 & 0.382 & 0.426 & 0.394 \\
\hline
\end{tabular}

${ }^{1}$ Standard errors of heritabilities ranged from 0.002 to 0.019 for Holstein, from 0.004 to 0.019 for Brown Swiss, and from 0.016 to 0.037 for Simmental.

${ }^{2} \mathrm{SCS}=\log _{2}\left(\mathrm{SCC} \times 100,000^{-1}\right)+3$.

$\% \mathrm{CY}_{\text {WATER }}$ ) or markedly lower (as in the case of the water and solids retained in the curd, which was around 0.60). No large between-breed difference was observed among these correlations.

The overall recoveries (i.e., $\mathrm{REC}_{\mathrm{SOLIDS}}$ and $\mathrm{REC}_{\mathrm{EN}-}$ ERGY) were strongly correlated with each other, both genetically and phenotypically (0.94 to 0.96). The other phenotypic correlations between nutrient recoveries were positive, but smaller than the corresponding genetic correlations. The estimated correlations among nutrient recoveries for Simmental cows were always lower than those of the other 2 breeds; this was likely due to the more limited data availability for Simmental cows, and was always associated with larger standard errors.

The total cheese $\left(\% \mathrm{CY}_{\mathrm{CURD}}\right)$ and solid (\% $\left.\mathrm{CY}_{\text {SOLIDS }}\right)$ yields (Table 6) were positively and moderately correlated with $\mathrm{REC}_{\mathrm{FAT}}$ and $\mathrm{REC}_{\mathrm{PROTEIN}}$, both phenotypi-

Table 5. Estimates of phenotypic $\left(\mathrm{r}_{\mathrm{p}}\right)$ and additive genetic $\left(\mathrm{r}_{\mathrm{A}}\right)$ correlations among cheese yields (\%CY; weight of fresh curd, curd solids, and curd water as percentage of weight of milk processed) and among milk nutrient recovery (REC; protein, fat, solids, and energy of the curd as percentage of the protein, fat, solids, and energy of the milk processed) in Holstein, Brown Swiss, and Simmental cows ${ }^{1}$

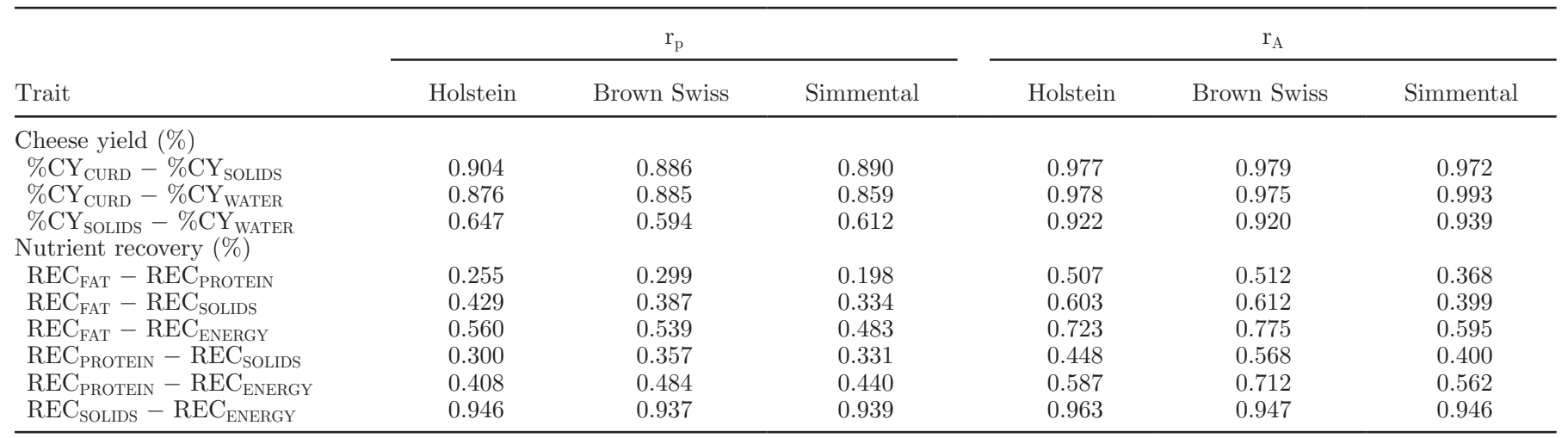

${ }^{1}$ Standard errors of additive genetic correlations ranged from 0.003 to 0.034 for Holstein, from 0.003 to 0.031 for Brown Swiss, and from 0.012 to 0.142 for Simmental. 
Table 6. Estimates of phenotypic $\left(\mathrm{r}_{\mathrm{p}}\right)$ and additive genetic $\left(\mathrm{r}_{\mathrm{A}}\right)$ correlations between cheese yields (\%CY; weight of fresh curd, curd solids, and curd water as percentage of weight of milk processed) and milk nutrient recovery (REC; protein, fat, solids, and energy of the curd as percentage of the protein, fat, solids, and energy of the milk processed) in Holstein, Brown Swiss, and Simmental cows ${ }^{1}$

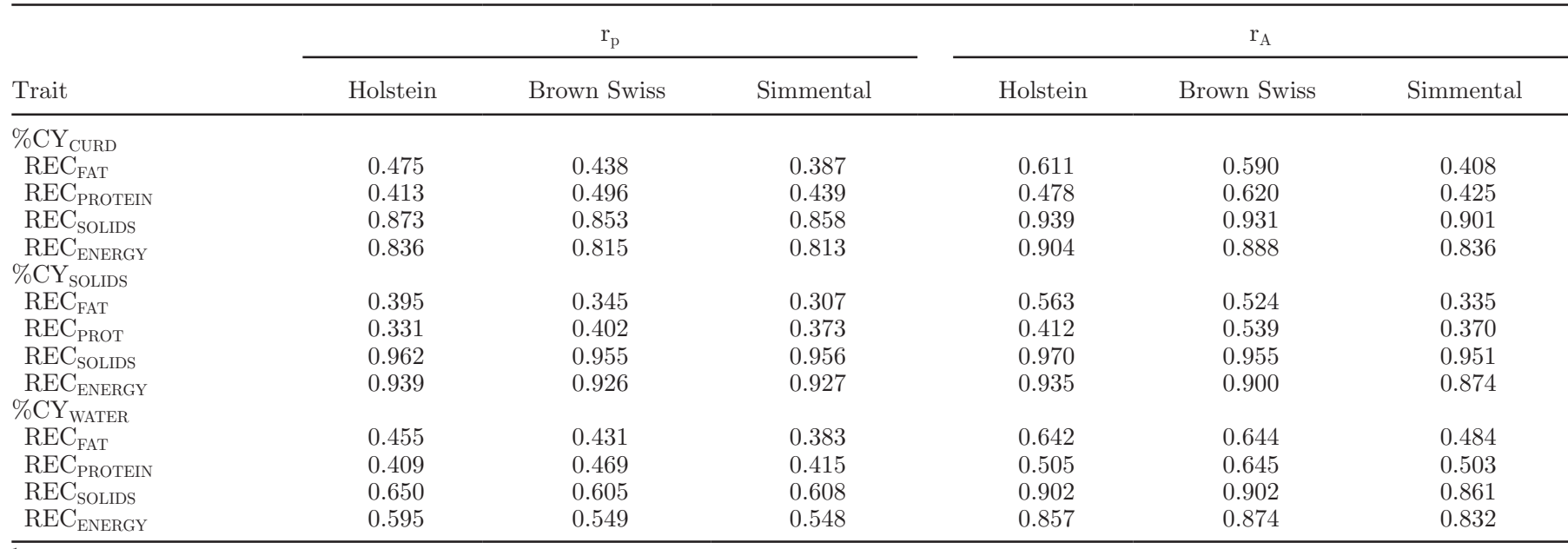

${ }^{1}$ Standard errors of additive genetic correlations ranged from 0.002 to 0.031 for Holstein, from 0.003 to 0.036 for Brown Swiss, and from 0.010 to 0.106 for Simmental.

cally (0.31 to 0.50$)$ and genetically (0.34 to 0.62$)$. Moreover, these $\% \mathrm{CY}$ were highly correlated with $\mathrm{REC}_{\mathrm{SOLIDS}}$ and $\mathrm{REC}_{\text {ENERGY }}$ from both points of view (0.81 to 0.97). The $\% \mathrm{CY}_{\text {WATER }}$ showed very strong genetic correlations with $\mathrm{REC}_{\text {SOLIDS }}$ and $\mathrm{REC}_{\text {ENERGY }}$, but the phenotypic correlations were lower than those of the other CY. Unexpectedly, the genetic correlations of \% $\mathrm{CY}_{\text {WATER }}$ with the nutrient recoveries were stronger than those of $\% \mathrm{CY}_{\text {SOLIDS }}$ and comparable to those observed for $\% \mathrm{CY}_{\mathrm{CURD}}$.

\section{Relationships of CY and REC with Milk Production and Composition}

The genetic and phenotypic correlations of the \% $\mathrm{CY}$ and REC traits with the milk production and composition traits are presented in Tables 7 and 8, respectively. In general, milk production displayed antagonistic relationships with all of the \% CY and REC traits in each breed, especially from the genetic point of view. The association of milk production with $\mathrm{REC}_{\mathrm{FAT}}$ and $\mathrm{REC}_{\text {PROTEIN }}$ was negative, but to a much smaller degree. The $\mathrm{dCY}$ showed moderate positive genetic and phenotypic correlations with all of the \%CY and REC traits in Holstein and Brown Swiss cows. In Simmental cows, the same genetic correlations were markedly lower, sometimes close to zero or even slightly negative, as in the case of $\mathrm{dCY}_{\mathrm{WATER}}$; the exceptions to this were the moderate correlations with $\mathrm{REC}_{\text {PROTEIN }}$. The milk fat and protein contents were much more correlated with cheese yields and overall nutrient recoveries than with their own recoveries in the curd (Table 8). The genetic correlations of $\mathrm{REC}_{\mathrm{FAT}}$ with the milk fat per- centage ranged from 0.17 to $0.42 ; \mathrm{REC}_{\text {PROTEIN }}$ showed a low genetic correlation with milk protein percentage in Simmental cows (0.10), but more moderate correlations in Holstein (0.24) and Brown Swiss (0.37) cows.

The milk lactose content showed moderate positive genetic and phenotypic correlations with all of the \%CY and REC traits except for those with $\% \mathrm{CY}_{\text {SOLIDS }}$ and $\mathrm{REC}_{\text {SOLIDS }}$, which were inconsistent or slightly negative. The SCS was both genetically and phenotypically independent of the CY and overall REC, but showed limited negative genetic correlations with $\mathrm{REC}_{\mathrm{PROTEIN}}$.

\section{DISCUSSION}

\section{Description of Dairy Systems}

Sturaro et al. (2013) described the dairy production environment of the geographical area covered by our study, identifying 4 main dairy systems. The first is the traditional alpine farming, based on summer highland grazing pastures, with smaller farms rearing mainly Brown Swiss and Simmental breeds. The second and third systems are similar to the previous one, but involve bigger farms. In the second, traditional feeding with hay and some compound feed is used without alpine grazing; in the third, more modern feeding regimens based on corn silage and often on TMR are used, but cows are still tied. In those systems, Brown Swiss and Holstein are the most represented breeds. Finally, a fourth system was identified, which is the typical intensive dairy system with open barns, free animals, milking parlor, often with TMR. This system involves the larger farms and accounts for half of the milk pro- 
Table 7. Estimates of phenotypic $\left(\mathrm{r}_{\mathrm{p}}\right)$ and additive genetic $\left(\mathrm{r}_{\mathrm{A}}\right)$ correlations of production traits with cheese yields $(\% \mathrm{CY}$; weight of fresh curd, curd solids, and curd water as percentage of weight of milk processed) and milk nutrient recovery (REC; protein, fat, solids, and energy of the curd as percentage of the protein, fat, solids, and energy of the milk processed) in Holstein, Brown Swiss, and Simmental cows ${ }^{1}$

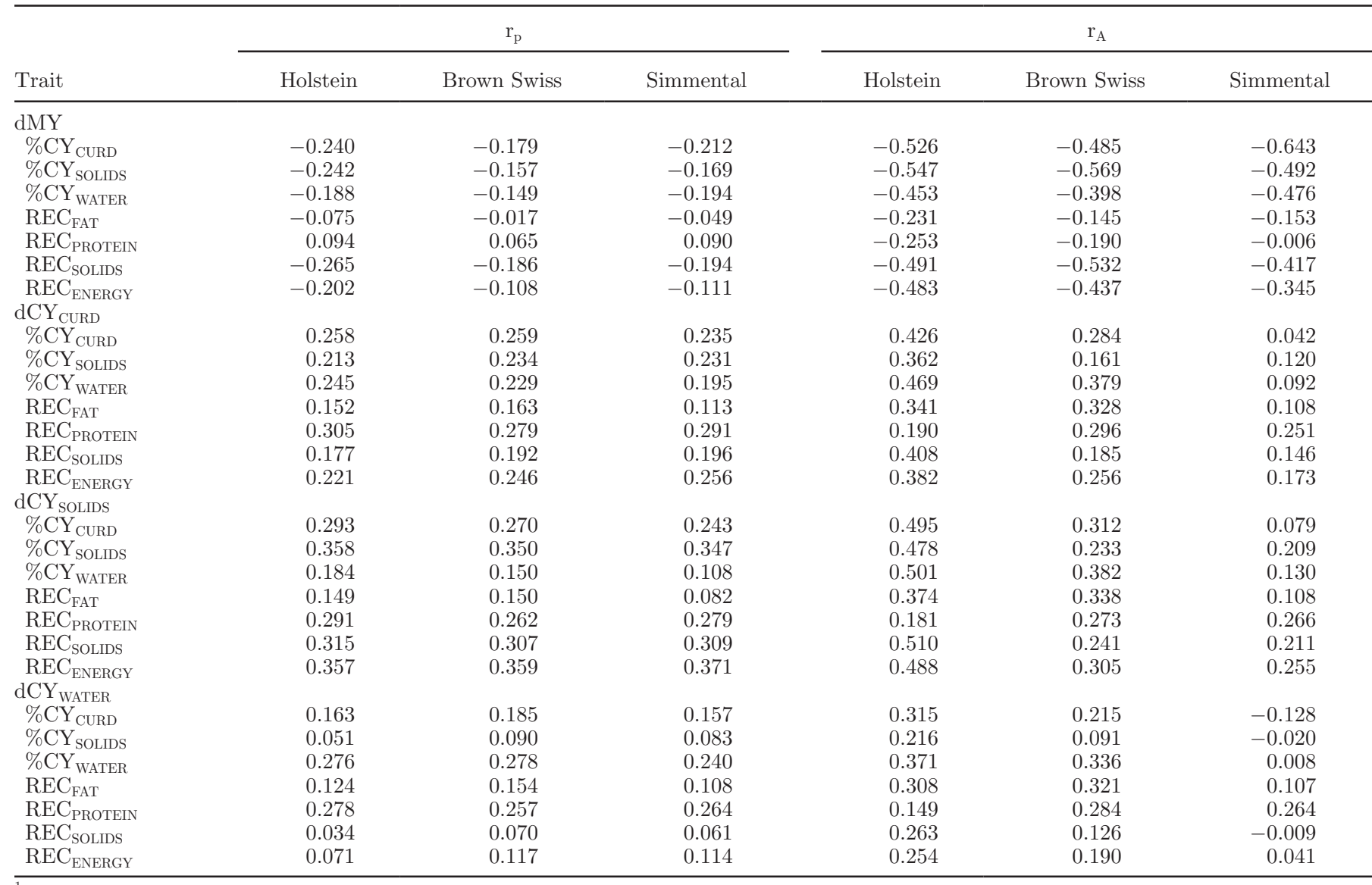

${ }^{1}$ Standard errors of additive genetic correlations ranged from 0.031 to 0.070 for Holstein, from 0.036 to 0.075 for Brown Swiss, and from 0.058 to 0.161 for Simmental. $d=$ daily; $M Y=$ milk yield.

duced in the area of the Trento Province. Within this system, Holstein is by far the most represented breed, followed by Brown Swiss. It is worth noting that a high incidence of multibreed herds was found in each of the production systems described by Sturaro et al. (2013).

\section{Genetic Parameters of CY and Curd Nutrient Recoveries}

Brown Swiss cows had higher \%CY than cows of the other studied breeds. Their $\% \mathrm{CY}_{\mathrm{CURD}}$ was $15.4 \%$, which was slightly higher than that reported by Cipolat-Gotet et al. (2013) for the same breed and mainly reflected a higher predicted water retention in the curd (8.3 vs. $7.8 \%$ ). The milk of Brown Swiss cows is generally considered to be particularly suitable for cheese production because of its favorable fat and protein compositions and its good aptitude for coagulation (Cecchinato et al., 2011b; Bittante et al., 2012). This breed therefore plays an important role in the Alpine dairy farming industry, where the large majority of milk is destined for the production of high-priced Protected Designation of Origin traditional cheeses (Bittante et al., 2011a,b). Notably, the greater FTIR-predicted \%CY of milk from Brown Swiss cows reflected not only higher fat and protein contents, but also higher REC traits. Obviously, the differences observed among the studied breeds could be at least partially attributable to the environments, feeding strategies, and management characteristics of the herds. In their analysis of Trento province dairy farms, Sturaro et al. (2013) found an unequal distribution of breeds across dairy systems with a greater proportion of Holstein Friesian cows in the more modern dairy farms, whereas the dual-purpose Simmental cows were more frequent in traditional Alpine farms, and Brown Swiss cows presented an intermediate distribution. They also found that the dairy system heavily affected the daily milk yield, but had only negligible 
Table 8. Estimates of phenotypic $\left(\mathrm{r}_{\mathrm{p}}\right)$ and additive genetic $\left(\mathrm{r}_{\mathrm{A}}\right)$ correlations of milk composition with cheese yields (\%CY; weight of fresh curd, curd solids, and curd water as percentage of weight of milk processed) and milk nutrient recovery (REC; protein, fat, solids, and energy of the curd as percentage of the protein, fat, solids, and energy of the milk processed) in Holstein, Brown Swiss, and Simmental cows ${ }^{1}$

\begin{tabular}{|c|c|c|c|c|c|c|}
\hline Trait & \multicolumn{3}{|c|}{$r_{p}$} & \multicolumn{3}{|c|}{$\mathrm{r}_{\mathrm{A}}$} \\
\hline \multicolumn{7}{|c|}{ Milk fat content } \\
\hline$\% \mathrm{CY}_{\text {SOLIDS }}$ & 0.919 & 0.903 & 0.907 & 0.945 & 0.916 & 0.941 \\
\hline$\% \mathrm{CY}_{\text {WATER }}$ & 0.399 & 0.312 & 0.350 & 0.755 & 0.713 & 0.747 \\
\hline $\mathrm{REC}_{\mathrm{FAT}}$ & 0.194 & 0.123 & 0.086 & 0.420 & 0.314 & 0.169 \\
\hline REC $_{\text {ENERGY }}$ & 0.880 & 0.845 & 0.858 & 0.896 & 0.785 & 0.833 \\
\hline \multicolumn{7}{|c|}{ Milk protein content } \\
\hline$\% \mathrm{CY}_{\mathrm{CURD}}$ & 0.724 & 0.704 & 0.723 & 0.875 & 0.880 & 0.813 \\
\hline$\% \mathrm{CY}_{\text {SOLIDS }}$ & 0.576 & 0.533 & 0.575 & 0.816 & 0.859 & 0.751 \\
\hline$\% \mathrm{CY}_{\text {WATER }}$ & 0.716 & 0.691 & 0.694 & 0.891 & 0.848 & 0.792 \\
\hline $\mathrm{REC}_{\mathrm{FAT}}$ & 0.239 & 0.204 & 0.195 & 0.285 & 0.223 & 0.008 \\
\hline REC $_{\text {PROTEIN }}$ & 0.104 & 0.158 & 0.120 & 0.244 & 0.373 & 0.099 \\
\hline$\% \mathrm{CY}_{\text {WATER }}$ & 0.179 & 0.210 & 0.165 & 0.203 & 0.216 & 0.388 \\
\hline $\mathrm{REC}_{\mathrm{FAT}}$ & 0.382 & 0.384 & 0.360 & 0.410 & 0.355 & 0.392 \\
\hline REC $_{\text {PROTEIN }}$ & 0.329 & 0.388 & 0.304 & 0.200 & 0.255 & 0.265 \\
\hline $\mathrm{REC}_{\text {SOLIDS }}$ & -0.187 & -0.179 & -0.210 & -0.027 & -0.037 & 0.012 \\
\hline REC $_{\text {ENERGY }}$ & -0.017 & 0.024 & -0.037 & 0.128 & 0.152 & 0.183 \\
\hline \multicolumn{7}{|l|}{$\mathrm{SCS}^{2}$} \\
\hline$\% \mathrm{CY}_{\mathrm{CURD}}$ & -0.013 & -0.033 & -0.006 & -0.146 & -0.089 & 0.090 \\
\hline$\% \mathrm{CY}_{\text {SOLIDS }}$ & 0.052 & 0.041 & 0.064 & -0.097 & -0.092 & 0.077 \\
\hline$\% \mathrm{CY}_{\text {WATER }}$ & -0.080 & -0.091 & -0.079 & -0.179 & -0.022 & 0.043 \\
\hline $\mathrm{REC}_{\mathrm{FAT}}$ & -0.116 & -0.112 & -0.099 & -0.300 & -0.123 & -0.200 \\
\hline REC $_{\text {PROTEIN }}$ & -0.313 & -0.268 & -0.270 & -0.270 & 0.030 & -0.112 \\
\hline $\mathrm{REC}_{\text {SOLIDS }}$ & 0.081 & 0.102 & 0.106 & -0.104 & 0.009 & 0.050 \\
\hline $\mathrm{REC}_{\text {ENERGY }}$ & 0.008 & 0.012 & 0.027 & -0.169 & -0.034 & -0.080 \\
\hline
\end{tabular}

${ }^{1}$ Standard errors of additive genetic correlations ranged from 0.005 to 0.070 for Holstein, from 0.011 to 0.078 for Brown Swiss, and from 0.022 to 0.169 for Simmental.

${ }^{2} \mathrm{SCS}=\log _{2}\left(\mathrm{SCC} \times 100,000^{-1}\right)+3$.

effects on the milk fat and casein contents. De Marchi et al. (2008) carried out a small-scale study on milk obtained from Holstein and Brown Swiss cows that were reared on 9 farms and used to produce 3 different traditional cheeses of Trento province. The results showed that a greater $\% \mathrm{CY}_{\mathrm{CURD}}$ was obtained from the milk of Brown Swiss cows, regardless of the cheese type, and that this was not totally explained by the differences in milk composition; instead, it also reflected the REC and water retention in the curd. In a very different production environment (that of Cheddar cheese), Mistry et al. (2002) demonstrated that the milk of Brown Swiss cows had a greater REC $\mathrm{FAT}_{\mathrm{T}}$ than that of Holstein cows. When comparing the use of whole milk from Holstein and Montbeliarde cows for the production of Cantal cheese, Martin et al. (2009) found that the latter was superior in both $\% \mathrm{CY}_{\mathrm{CURD}}$ and $\% \mathrm{CY}_{\text {SOLIDS }}$, and the $\% \mathrm{CY}_{\text {SOLIDS }}$ was about $50 \%$ higher than would be expected based on the observed differences in the milk fat and protein contents. In 2 previous studies, Verdier-Metz et al. $(1995,1998)$ examined vat milk composition during Saint-Nectaire cheese production from the partial skim milk of Holstein, Montbeliarde, and Tarentaise cows and found that $\% \mathrm{CY}_{\text {CURD }}$ and $\mathrm{REC}_{\text {SOLIDS }}$ were not affected by breed. These results support the need for the use of specific prediction of cheese-yield (such as the FTIR prediction of \% $\mathrm{CY}_{\mathrm{CURD}}$ and $\% \mathrm{CY}_{\text {SOLIDS }}$ ), or the need to combine $\mathrm{REC}_{\mathrm{FAT}}$ and $\mathrm{REC}_{\text {PROTEIN }}$ with milk fat and protein contents because milk composition alone is not able to fully characterize the value of milk for cheese production.

In the present work, the additive genetic variances of \% CY were found to be heterogeneous across breeds, with 2-fold higher values in Holstein cows compared with Simmental cows, whereas Brown Swiss cows had intermediate values. This heterogeneity may reflect 
between-breed differences in the genetic basis of the milk fat and protein contents and of the \% $\mathrm{CY}$ traits, but also in the herd sizes and farming systems (Sturaro et al., 2013). The residual variances and permanent environmental variances were similar across breeds (data not shown), so the heritability values of these parameters reflected breed-specific differences in the additive genetic variance. In studying individual cheeses produced from 1,272 Brown Swiss cows reared in the same area as those of the present study, Bittante et al. (2013) reported estimated additive genetic variances for the $\% \mathrm{CY}$ and REC traits greater than those obtained in our study for the FTIR-predicted traits of the same breed, with the exception of $\% \mathrm{CY}_{\mathrm{CURD}}$. In a subsequent study, the same authors found that estimates of additive genetic variances for FTIR-predicted \%CY and REC traits were lower than those of the corresponding laboratory measurements on the same animals (Bittante et al., 2014). Notably, the latter values were very similar to those obtained in the present study. This indicates that FTIR predictions can capture most of the population-level genetic variation among cheese yields, with limited loss of information. Interestingly, estimates of genetic parameters for FTIR predictions of the different cheese yields in our study were similar, even when large differences in the accuracy of calibrations existed. Despite the less satisfactory calibration parameters compared with $\% \mathrm{CY}_{\mathrm{CURD}}$ and $\% \mathrm{CY}_{\text {SOLIDS }}$ (Ferragina et al., 2013), \% $\mathrm{CY}_{\text {WATER }}$ showed comparable heritability values.

This was confirmed also by Bittante et al. (2014), who found that also the herd and residual variances were smaller for FTIR predicted than for laboratory measured \% CY and REC traits. The consequence is that heritability estimates of observed and predicted values were similar for all traits, regardless of the accuracy of calibrations. Moreover, the genetic correlations between measures and predictions were high, confirming that a FTIR calibration judged poor for predicting a phenotype, could yield good predictions when applied to the genetic evaluation of animals.

Similar to the findings of Bittante et al. (2013) on laboratory-measured traits, the genetic correlations between the different FTIR predicted \%CY traits were largely over 0.9 in the present study, suggesting that selection based on one such trait could effectively improve the others. Among them, $\mathrm{CY}_{\mathrm{CURD}}$ is probably the trait of choice, because it showed higher additive genetic variance, heritability, and repeatability in all 3 of the tested breeds. As protein and fat are the main solid components of the curd, CY is directly related to their retention in the curd (Fagan et al., 2007; Hallén et al., 2010).
In the present study, $\mathrm{REC}_{\mathrm{FAT}}$ ranged from 86 to $87 \%$, whereas $\mathrm{REC}_{\text {PROTEIN }}$ was between 76.6 and $78.2 \%$. Among all of the recoveries, $\mathrm{REC}_{\text {PRoteIn }}$ was the most promising trait, as it consistently displayed a larger heritability in all 3 tested breeds. Similar to the previously described results, between-trait differences in the accuracy of the prediction equations (Ferragina et al., 2013) were not reflected in the estimated heritability of the nutrient recoveries. These findings support the conclusion that, although a loss of variation is implicit when FTIR predictions are used instead of measured traits, this has only a limited effect on the potential of the analysis to highlight genetic differences between animals.

The genetic correlations between $\mathrm{REC}_{\mathrm{FAT}}$ and $\mathrm{REC}_{\text {PROTEIN }}$ were positive and consistent, but not very high (from 0.37 to 0.51 ), whereas the corresponding phenotypic correlations were only moderate. Using laboratory-measured traits, Bittante et al. (2013) found a similar pattern in these correlations, even though their estimated values were lower than those obtained in the present study. Therefore, the recoveries of individual nutrients do not appear to be highly associated with one another. This was further confirmed by their respective genetic relationships with $\mathrm{REC}_{\text {SOLIDS }}$, which ranged from 0.40 to 0.61 .

Regarding laboratory-measured traits, REC and $\mathrm{REC}_{\text {ENERGY }}$ were highly correlated with $\% \mathrm{CY}_{\mathrm{CURD}}$ and $\% \mathrm{CY}_{\text {SOLIDS }}$ and showed consistent genetic correlations with $\% \mathrm{CY}_{\text {WATER }}$. In contrast, the genetic and phenotypic associations of $\mathrm{REC}_{\mathrm{FAT}}$ and $\mathrm{REC}_{\mathrm{PROTEIN}}$ with the $\% \mathrm{CY}$ were lower than those of overall recoveries. Hence, the improvement of CY seems to be related to increasing both the nutrient retention and the waterholding capacity of the curd. The relevance of water retention was also confirmed by the genetic and phenotypic correlations of the individual nutrient recoveries with $\% \mathrm{CY}_{\text {WATER}}$, which were higher than that with $\% \mathrm{CY}_{\text {SOLIDS }}$ in all 3 tested breeds.

\section{Genetic Relationship with Milk Production and Composition}

The genetic correlations of the \%CY and REC with milk production and composition are important to our understanding of how cheese technological parameters respond to the selection of dairy cattle. They also allow us to explore the potential use of direct selection to improve cheese aptitude.

The farms included in our study were small, located in a mountainous area, and often represented more than one breed (Sturaro et al., 2013). Thus, the production environment, herd structure, and herd management 
yielded heritability values for dMY that were markedly lower than those reported in national genetic evaluations of the 3 breeds. In all 3 of the breeds studied in the present work, dMY displayed antagonistic genetic relationships with all of the $\% \mathrm{CY}$ traits, whereas the phenotypic correlations were also negative, but only moderately so. A negative effect of increased milk production on $\% \mathrm{CY}$ would be expected, mainly because of the known negative genetic correlation between daily milk yield and milk fat and protein contents, but also due to the relationships between daily milk yield and the curd recovery of the 2 nutrients. This was also indirectly confirmed by the strong and favorable relationships between the milk fat and protein contents and \%CY (Table 8). Bittante et al. (2013) obtained similar results. However, in their study of the laboratory-measured \% CY and REC traits, the negative correlations between dMY and the \% CY were lower in magnitude, even though they were associated with relatively large areas of the posterior distributions of the estimated parameters.

The TS and energy recoveries behaved similarly to the $\% \mathrm{CY}$ traits, as they were negatively associated with dMY and positively related to milk composition. However, the latter associations depended on the dilution of lactose (which is lost in the whey) when the milk TS increase rather than the higher fat and protein retentions. In fact, the $\mathrm{REC}_{\text {PRotein }}$ showed very weak negative genetic correlations with dMY (these were even sometimes inconsistent, as in the case of $\mathrm{REC}_{\text {Protein }}$ in Simmental cows), and the phenotypic correlations were null. An increase in dMY seemed to have a very limited effect on the ability of the curd to retain milk nutrients. The fat and protein contents of the milk were moderately correlated (in a favorable direction) with their respective recoveries in the curd for Holstein and Brown Swiss cows, but poorly correlated in Simmental cows. In contrast, the study of Bittante et al. (2013) on laboratory-measured traits found a negligible correlation between $\mathrm{REC}_{\mathrm{FAT}}$ and the milk fat percentage and $\mathrm{REC}_{\text {PRotein }}$ and the protein content of the milk.

The breeding goals and selection indices used worldwide for dairy cattle include the milk protein and fat yields or percentages (Miglior et al., 2005), and breeders indirectly select for the aptitude of milk for cheese production by seeking to increase its protein and fat contents. Based on the genetic correlations estimated in the present study, it might be expected that, due to their favorable relationship, all of the $\% \mathrm{CY}$ traits would also be improved by such selection. However, given that the daily protein and fat quantities are also positively correlated with milk production, the consistent negative genetic correlations between $\mathrm{dMY}$ and $\% \mathrm{CY}$ would partially counteract this positive effect. Furthermore, there is also genetic variability in the retention of milk fat and protein. The improvement of the milk protein and fat contents would only marginally affect the individual nutrient recoveries in the curd, as the favorable genetic correlations between these traits are only moderate, whereas those of dMY with $\mathrm{REC}_{\text {PROTEIN }}$ and $\mathrm{REC}_{\mathrm{FAT}}$ are slightly negative.

Thus, based on the results of the present and previous studies, direct selection of $\% \mathrm{CY}$ could be a more efficient means of capturing all of the genetic variance related to milk technological properties, which is not completely explained by the milk composition. The prediction of \% CY can be easily obtained on the same samples and with the same instrument used for prediction of milk fat and protein contents. Furthermore, opportunity exists to directly exploit the genetic variations of $\mathrm{REC}_{\text {PROTEIN }}$ and $\mathrm{REC}_{\mathrm{FAT}}$, as they are nearly independent of the milk composition and could provide useful information when farmers seek to select for improved cheese yield.

\section{CONCLUSIONS}

This study provided the first estimation of genetic parameters of 3 dairy breeds for $\% \mathrm{CY}$ and nutrient recoveries in the curd at population level using their FTIR predictions. All of the predicted traits proved to be heritable and displayed heritability values comparable to those of the measured traits, although a loss of genetic variability was generally observed. The estimated heritabilities of the \%CY and REC were similar in magnitude to those of the milk fat and protein percentages and higher than that of dMY. Although the between-breed differences were limited from a biological standpoint, the heritabilities were systematically lower in Simmental cows (except for $\mathrm{REC}_{\text {PROTEIN }}$ ) compared with Holstein and Brown Swiss cows, which were fairly homogeneous in these measures. Our estimates of the genetic correlations of \% CY and REC with milk production and composition provide evidence that the current selection paradigm used in dairy cattle may have only limited effects on the technological parameters of milk for cheese production. Instead, genetic variations in $\% \mathrm{CY}$ and (in particular) the recovery of protein and fat in the curd, which is not explained by the milk protein and fat contents, could be directly selected to improve the aptitude of milk for cheese production. The applicability of routine FTIR-based predictions for these traits means that we have ready and inexpensive access to a large amount of phenotypic data with repeated observations for cows within and across lactations. This should allow for the routine genetic evaluation of $\% \mathrm{CY}$ 
and REC in the curd, in addition to currently studied production traits, and the establishment of new direct selection strategies for improved cheese yield.

\section{ACKNOWLEDGMENTS}

The authors thank the Autonomous Province of Trento (Italy) for funding the project, and the Superbrown Consortium of Bolzano and Trento (Trento, Italy) for the support in sampling and recording activities.

\section{REFERENCES}

Arnould, V. M.-R., H. Hammami, H. Soyeurt, and N. Gengler. 2010 Short communication: Genetic variation of saturated fatty acids in Holsteins in the Walloon region in Belgium. J. Dairy Sci. 93:4391-4397.

Arnould, V. M.-R., H. Soyeurt, N. Gengler, F. G. Colinet, M. V. Georges, C. Bertozzi, D. Portetelle, and R. Renaville. 2009. Genetic analysis of lactoferrin content in bovine milk. J. Dairy Sci. 92:2151-2158.

Bastin, C., N. Gengler, and H. Soyeurt. 2011. Phenotypic and genetic variability of production traits and milk fatty acid contents across days in milk for Walloon Holstein first-parity cows. J. Dairy Sci. 94:4152-4163.

Bittante, G., and A. Cecchinato. 2013. Genetic analysis of the Fouriertransform infrared spectra of bovine milk with emphasis to individual wavelengths related to specific chemical bonds. J. Dairy Sci. 96:5991-6006.

Bittante, G., A. Cecchinato, N. Cologna, M. Penasa, F. Tiezzi, and M. De Marchi. 2011a. Factors affecting the incidence of first-quality wheels of Trentingrana cheese. J. Dairy Sci. 94:3700-3707.

Bittante, G., C. Cipolat-Gotet, and A. Cecchinato. 2013. Genetic parameters of different measures of cheese yield and milk nutrient recovery or whey loss traits from unprocessed bovine milk samples. J. Dairy Sci. 96:7966-7979.

Bittante, G., N. Cologna, A. Cecchinato, M. De Marchi, M. Penasa, F. Tiezzi, I. Endrizzi, and F. Gasperi. 2011b. Monitoring of sensory attributes used in the quality payment system of Trentingrana cheese. J. Dairy Sci. 94:5699-5709.

Bittante, G., A. Ferragina, C. Cipolat-Gotet, and A. Cecchinato. 2014. Comparison between genetic parameters of cheese yield and nutrient recovery or whey loss traits measured from individual model cheese-making methods or predicted from unprocessed bovine milk samples using Fourier-transform infrared spectroscopy. J. Dairy Sci. 97:6560-6572.

Bittante, G., M. Penasa, and A. Cecchinato. 2012. Invited review: Genetics and modeling of milk coagulation properties. J. Dairy Sci. 95:6843-6870.

Brandt, M., A. Haeussermann, and E. Hartung. 2010. Invited review: Technical solutions for analysis of milk constituents and abnormal milk. J. Dairy Sci. 93:427-436.

Cecchinato, A., M. De Marchi, L. Gallo, G. Bittante, and P. Carnier. 2009. Mid-infrared spectroscopy as indicator traits in breeding programs for enhanced coagulation properties of milk. J. Dairy Sci. 92:5304-5313.

Cecchinato, A., M. De Marchi, M. Penasa, A. Albera, and G. Bittante. 2011a. Near-infrared reflectance spectroscopy predictions as indicator traits in breeding programs for enhanced beef quality. J. Anim. Sci. 89:2687-2695.

Cecchinato, A., M. Penasa, M. De Marchi, L. Gallo, G. Bittante, and P. Carnier. 2011b. Genetic relationships of coagulation properties with milk yield, quality and acidity estimated using coagulating and noncoagulating milk information in Brown Swiss and Holstein Friesian cows. J. Dairy Sci. 94:4205-4213.
Cipolat-Gotet, C., A. Cecchinato, M. De Marchi, and G. Bittante. 2013. Factors affecting variation of different measures of cheese yield and milk nutrient recovery from an individual model cheesemanufacturing process. J. Dairy Sci. 96:7952-7965.

Dagnachew, B. S., T. H. Meuwissen, and T. Ådnøy. 2013. Genetic components of milk Fourier transform infrared spectra used to predict breeding values for milk composition and quality traits in dairy goats. J. Dairy Sci. 96:5933-5942.

De Marchi, M., G. Bittante, R. Dal Zotto, C. Dalvit, and M. Cassandro. 2008. Effect of Holstein Friesian and Brown Swiss breeds on quality of milk and cheese. J. Dairy Sci. 91:4092-4102.

Emmons, D. B. 1993. Economic importance of cheese yield. Pages 10-11 International Dairy Federation Special Isuue 9301, Factors Affecting the Yield of Cheese. International Dairy Federation, Brussels, Belgium.

Emmons, D. B., C. A. Ernstrom, C. Lacroix, and P. Verret. 1990. Predictive formulas for yield of cheese from composition of milk: A review. J. Dairy Sci. 73:1365-1394.

Fagan, C. C., M. Castillo, F. A. Payne, C. P. O'Donnell, and D. J. O'Callaghan. 2007. Effect of cutting time, temperature, and calcium on curd moisture, whey fay losses, and curd yield by response surface methodology. J. Dairy Sci. 90:4499-4512.

Ferragina, A., C. Cipolat-Gotet, A. Cecchinato, and G. Bittante. 2013. The use of Fourier-transform infrared spectroscopy to predict cheese yield and nutrient recovery or whey loss traits from unprocessed bovine milk samples. J. Dairy Sci. 96:7980-7990.

Groeneveld, E., M. Kovac, and N. Mielenz. 2010. VCE user's guide and reference manual version 6.0. Institute of Farm Animal Genetics, Neustadt, Germany.

Hallén, E., A. Lundén, T. Allmere, and A. Andrén. 2010. Casein retention in the curd and loss of casein into whey at chymosin-induced coagulation of milk. J. Dairy Res. 77:71-76.

International Committee for Animal Recording (ICAR). 2012. International Agreement of Recordings Practices - Guidelines Approved by the General Assembly held in Cork, Ireland, on June 2012. ICAR. Rome, Italy.

International Dairy Federation. 2013. The World Dairy Situation. Bulletin 470/2013. International Dairy Federation, Brussels, Belgium.

Karoui, R., G. Downey, and C. Blecker. 2010. Mid-infrared spectroscopy coupled with chemometrics: A tool for the analysis of intact food systems and the exploration of their molecular structureQuality relationship - A review. Chem. Rev. 110:6144-6168.

Karoui, R., M. Hammami, H. Rouissi, and C. Blecker. 2011. Mid infrared and fluorecence spectroscopies coupled with factorial discriminant analysis technique to identify sheep milk from different feeding systems. Food Chem. 127:743-748.

Martin, B., D. Pomies, P. Pradel, I. Verdier-Metz, and B. Remond. 2009. Yield and sensory properties of cheese made with milk form Holstein and Montbeliarde cows milked twice or once daily. J. Dairy Sci. 92:4730-4737.

Miglior, F., B. L. Muir, and B. J. van Dormaal. 2005. Selection indices in Holstein cattle of various country. J. Dairy Sci. 88:1255-1263.

Mistry, V. V., M. J. Brouk, K. M. Kasperson, and E. Martin. 2002. Cheddar cheese from milk of Holstein and Brown Swiss cows. Milchwissenschaft 57:19-23.

Neumaier, A., and E. Groeneveld. 1998. Restricted maximum likelihood estimation of covariances in sparse linear models. Genet. Sel. Evol. 30:3-26.

Othmane, M. H., J. A. Carriedo, L. F. de la Fuente Crespo, and F. San Primitivo. 2002a. An individual laboratory cheese-making method for selection in dairy ewes. Small Rumin. Res. 45:67-73.

Othmane, M. H., J. A. Carriedo, F. San Primitivo, and L. F. De La Fuente. 2002b. Genetic parameters for lactation traits of milking ewes: Protein content and composition, fat, somatic cells and individual laboratory cheese yield. Genet. Sel. Evol. 34:581-596.

Rutten, M. J. M., H. Bovenhuis, J. M. L. Heck, and J. A. M. van Arendonk. 2011. Predicting bovine milk protein composition base on Fourier transform infrared spectra. J. Dairy Sci. 94:5683-5690.

Rutten, M. J. M., H. Bovenhuis, K. A. Hettinga, H. F. J. van Valenberg, and J. A. M. van Arendonk. 2009. Predicting bovine milk 
fat composition using infrared spectroscopy based on milk samples collected in winter and summer. J. Dairy Sci. 92:6202-6209.

Rutten, M. J. M., H. Bovenhuis, and J. A. M. van Arendonk. 2010. The effect of the number of observations used for Fourier transform infrared model calibration for bovine milk fat composition on the estimated genetic parameters of the predicted data. J. Dairy Sci. 93:4872-4882.

Soyeurt, H., F. G. Colinet, V. M.-R. Arnould, P. Dardenne, C. Bertozzi, R. Renaville, D. Portetelle, and N. Gengler. 2007a. Genetic variability of lactoferrin content estimated by mid-infrared spectrometry in bovine milk. J. Dairy Sci. 90:4443-4450.

Soyeurt, H., A. Gillon, S. Vanderick, P. Mayeres, C. Bertozzi, and N. Gengler. 2007b. Estimation of heritability and genetic correlations for the major fatty acids in bovine milk. J. Dairy Sci. 90:4435-4442.

Soyeurt, H., I. Misztal, and N. Gengler. 2010. Genetic variability of milk components based on mid-infrared spectral data. J. Dairy Sci. 93:1722-1728.
Sturaro, E., E. Marchiori, G. Cocca, M. Penasa, M. Ramanzin, and G. Bittante. 2013. Dairy systems in mountainous areas: Farm animal biodiversity, milk production and destination, land use and land use. Livest. Sci. 1-3:157-168.

Verdier-Metz, I., J. B. Coulon, and P. Pradel. 2001. Relationship between milk fat and protein contents and cheese yield. Anim. Res. 50:365-371.

Verdier-Metz, I., J. B. Coulon, P. Pradel, and J. L. Berdaguè. 1995. Effect of forage type and cow breed on the characteristics of matured Saint-Nectaire cheeses. Lait 75:523-533.

Verdier-Metz, I., J. B. Coulon, P. Pradel, C. Viallon, and J. L. Berdaguè. 1998. Effect of forage conservation (hay or silage) and cow breed on the coagulation properties of milk and on the characteristics of ripened cheeses. J. Dairy Res. 65:9-21. 